\title{
Floods and money: funding drainage and flood control in coastal Flanders from the thirteenth to the sixteenth centuries
}

\author{
TIM SOENS*
}

AbStRact. From the High Middle Ages on, the coastal wetlands of the North Sea area have been intensively reclaimed and settled. In order to enable intensive agricultural production in these areas, a complex drainage and flood control system was gradually installed, one that demanded a permanent investment of huge amounts of capital and labour. As the maintenance of the water control system was vital for the coastal agro-system, the long-term evolution of investments is an important, yet rarely used, indicator of the economic, social and environmental fortunes of the coastlands. Based on new and very early serial data on water control funding in late medieval Flanders, this article argues that long-term fluctuations in the funding of drainage and flood control were first and foremost related to structural changes within the coastal economy, where an overall decline of investment levels ran parallel to the fourteenth-century crisis of the peasant smallholding economy in this region. Exogenous pressures on the other hand, such as storm surges, only provoked a shortterm disruption of investments.

1. INTRODUCTION: ENVIRONMENT, ECONOMY ANDTHEFUNDING OF DRAINAGE AND FLOOD CONTROL

Above a certain level of population and intensity of land use, the construction of sea walls, drainage ditches and sluices was a precondition to allow permanent settlement and farming in a coastal wetland. The method of funding this kind of capital-intensive activity still remains unclear, especially for the period before 1500 when serial data are scarce. A few

\footnotetext{
* University of Antwerp, Belgium.
} 
pioneering studies have used data on dyke repairs to reveal the impact of (extreme) weather conditions on the rural economy. ${ }^{1}$ More recently, climate historians have begun to explore investments in the water control system as an indicator by proxy for weather conditions or climate disturbances, especially with regard to storm or river flooding. ${ }^{2}$ In both cases it is presumed that expenditure on dykes and drains merely reacted to environmental 'challenges', such as storms, cold winters or wet summers. Flood disasters in particular have been studied as triggers of large investment programmes, technological innovations and institutional changes. ${ }^{3}$ In recent times as well, large investment projects with regard to flood control almost invariably followed major flooding disasters. ${ }^{4}$ On the other hand, some geographers and historians also reacted against what might be labelled as a new wave of climate determinism in history. ${ }^{5}$ Society only seldom just 'answered' to 'challenges' posed by these kinds of exogenous circumstances: as soon as the population reached a certain density, socalled natural disasters were conditioned or even produced by men and thus responsive to changing human preferences and policies. ${ }^{6}$ In this article I will follow this line of reasoning, and try to explain investments in flood and water control from a societal perspective. I will argue that a clear economic rationale often determined the evolution of water management funding, and that structural changes in investment levels can often be better explained by economic transformations than by climate changes. The late medieval period offers an excellent time frame for this research. In the literature an increased 'storminess' in the North Sea area loosely connected to the climatic transition from the medieval warm period to the Little Ice Age is generally accepted. Beginning during the 1250s, reaching peaks in the 1280s - the Age of Storms in Southern England - and around 1400, this transition continued, with ups and downs, until the late sixteenth century. ${ }^{7}$

Although many North Sea wetlands witnessed important urban developments from the high medieval period onwards, the wetland economy remained a rural economy throughout the pre-modern period. For the sake of analysis I will thus consider capital investment in flood protection and drainage as a form of re-investment of the surplus product generated by this rural economy. When investment is directed towards improvement rather than just maintenance and repair, gross capital formation in agriculture increases. Higher capital input in return is one means of raising agricultural productivity. ${ }^{8}$ Whether or not this actually happened depended on the income strategies of local farmers and landlords. In a commercial rural economy, landlords and tenant farmers are often attributed with a higher propensity to make substantial capital investments than peasants and lords in a feudal economy. For Robert Brenner, higher 
capital investment, leading to an increase in productivity, resulted from the creation of capitalist social property relations, with tenant farmers forced to invest if they wanted to survive the competition for holdings, and landlords also investing in their estates to keep them attractive for substantial farmers. ${ }^{9}$ Other authors have opposed this view, pointing to high capital investments by landowning smallholders, for instance in the Dutch Republic during the sixteenth and seventeenth centuries. ${ }^{10}$ For England as well, it has been suggested that (substantial) peasants enjoying secure tenure in regions of open-field agriculture could realise capital investments and output gains that matched those realised by landlords and capitalist farmers after enclosure. ${ }^{11}$ In water management too, it can be questioned whether peasant societies - driven by risk-aversion strategies ${ }^{12}$ - could adopt an equally flexible water management and investment pattern, and could reach total investment levels that equalled or even exceeded those in a commercialised rural economy, where investments were made in pursuit of productivity and output gains, but were at the same time constrained by the income strategies of nonproducing, absentee, landowners.

The Flemish coastal plain, between the end of the thirteenth and the end of the sixteenth century, offers an excellent test case for this study (Figure 1). Just like many other parts of the North Sea coastal area, Flanders witnessed many flood problems in this period, with the loss of 1000 s of hectares of land and over 100 villages. $^{13}$ Economically, the Flemish coastal plain between 1280 and 1570 was a region in transition. Around 1280, smallholders were still predominant in this area. Most of them enjoyed secure property rights over their land and holdings, often paying just a low customary rent, or even no rent at all. To survive, many of these smallholders needed an additional income via various activities such as wool processing, fishing and especially peat digging and salt making, activities that were practised on a very large scale in this area. Selling agricultural and proto-industrial products in the dense urban and rural market network of the coastal plain, and purchasing whatever grain their tiny holdings were unable to produce, these smallholders were certainly involved in the market economy. But just as in other peasant economies of pre-industrial Europe, a considerable degree of market involvement did not prevent the economy of the thirteenth-century coastal plain from being a true peasant economy, where the access to land, labour and capital was still by and large ungoverned by the market. ${ }^{14}$ By the middle of the sixteenth century, rural society had profoundly changed in this part of Europe. Both peasant landownership and population levels had seriously declined, and proto-industrial activities all but vanished in the area. Short-term leaseholding had become the dominant form 


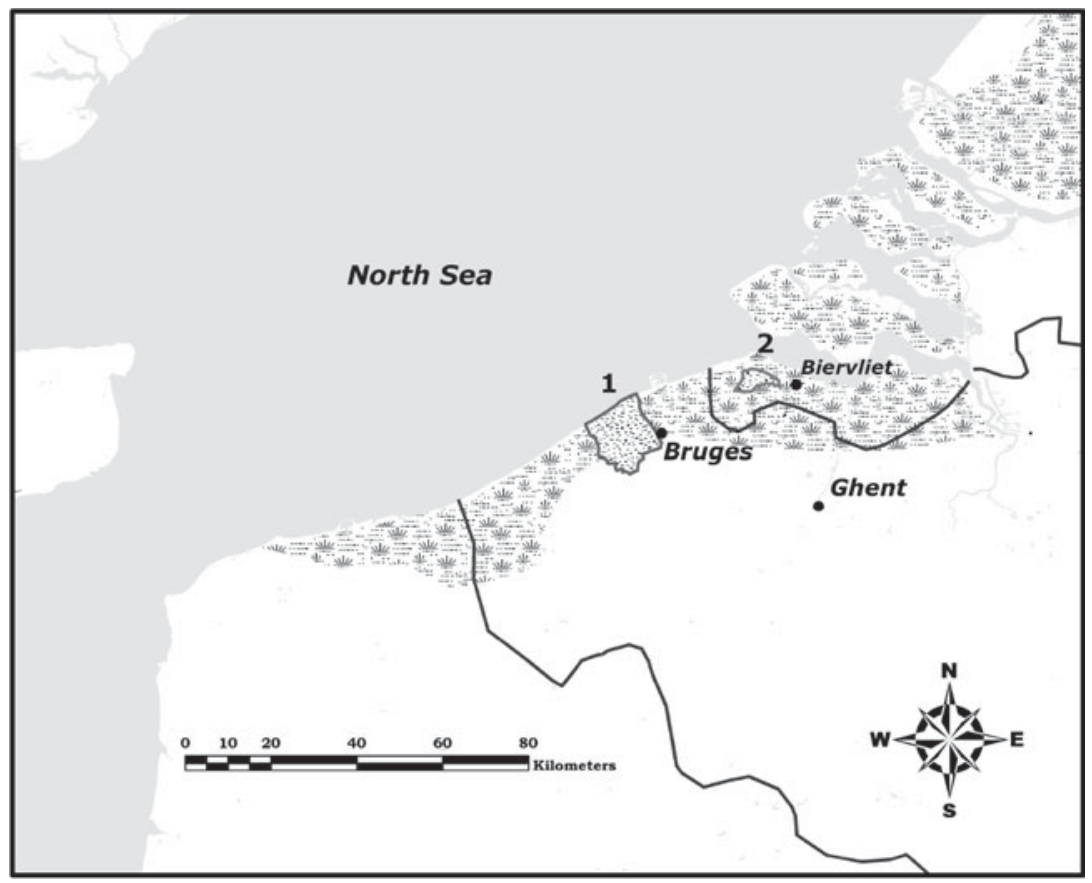

FIGURE 1. Map of coastal Flanders, with principal places mentioned in the text (1: Blankenbergse Watering; 2: Oude Yevene Watering).

of landholding: in some parts of the coastal plain about 90 per cent of the land was held in short-term leaseholds. Farm sizes were steadily growing, as many peasant farms were abandoned and their land incorporated in larger leasehold farms. The latter farms increasingly specialised in arable farming or stock breeding for the urban market. Although this was not yet the grand agriculture practised in the area during the seventeenth and eighteenth centuries, when one-third of all farms exceeded 50 hectares, it is clear that the once-flourishing peasant economy had already vanished by the middle of the sixteenth century in the area. ${ }^{15}$

The archival evidence concerning the funding of water management in coastal Flanders is exceptionally abundant from an early date onwards, thanks to the rich archives of some major ecclesiastical landowners such as St John's hospital in Bruges whose yearly accounts date back to the 1280s. This is also the case for some water boards situated in the areas surrounding Bruges. A water board (Dutch: waterschap or watering; French: wateringue) was an autonomous local authority responsible for the maintenance of drainage and flood control in coastal areas, ranging 
from a single, embanked piece of land (a so-called 'polder') to whole parishes. Water boards were organised into compulsory associations of landowners collaborating to ensure the maintenance and repair of sea walls, drains, ditches and sluices. They can be found all over the North Sea area from the later Middle Ages onwards, but the Flemish water boards were quite unique because of their early centralisation of maintenance and repair works. ${ }^{16}$ In other parts of the North Sea area, local water boards limited themselves to supervision and inspection of works performed by individual landowners well into the fifteenth or sixteenth century, but in the Flemish commercial metropolis of Bruges and its surroundings, water boards started to perform these works themselves as early as the second half of the thirteenth century. They did so by hiring labour or outsourcing work on dykes, drains and sluices, and they financed these activities through a uniform water tax - called a scot or geschot-paid by each landowner in proportion to his or her landed property. ${ }^{17}$ Major decisions were usually taken by a general assembly of landowners. The same general assembly also elected an executive body. For this reason, water boards are sometimes perceived as a form of corporate collective action, comparable with commons and guilds. ${ }^{18}$

2. WATER MANAGEMENT FUNDING UNTIL 1400

Intensive capital investment and large drainage or embankment projects are often associated with the seventeenth century, when venture capitalists and Dutch engineers such as Cornelis Vermuyden or Jan Adriaanszoon Leeghwater operated, often backed by explicit state support. They are credited with turning areas previously used 'suboptimally' into better performing systems, with a higher agricultural output and better drainage conditions, whereas the peasants that previously occupied these areas were deemed to be both unable and unwilling to engage in this kind of improvement. ${ }^{19}$ In his famous book on the drainage of the English fenlands, H. C. Darby describes a peasant society unable to maintain capital-intensive infrastructure such as dykes and drains on a more than temporary basis. From the thirteenth century royal assistance had to be called on to modify and enforce maintenance regulations. Financial assistance was also needed, at first provided by large abbeys and later on by capitalist entrepreneurs. ${ }^{20}$

Data from the Flemish coastal plain, however, reveal that the annual capital input in the water control system was already quite high around 1400 when the region was still a predominantly peasant economy, and that this capital was not provided by capitalist investors but by peasant communities themselves. For the rural surroundings of Bruges, the capital 
TABLE 1

Capital investment in 21 water boards near Bruges

(Flemish pounds (l. groten), 1403-1408) ${ }^{a}$

\begin{tabular}{|c|c|c|c|c|c|c|}
\hline Water board & $\begin{array}{c}\text { Size } \\
\text { (hectares) }\end{array}$ & $\begin{array}{c}1403- \\
1404\end{array}$ & $\begin{array}{c}1404- \\
1405\end{array}$ & $\begin{array}{c}1405- \\
1406\end{array}$ & $\begin{array}{c}1406- \\
1407\end{array}$ & $\begin{array}{r}1407- \\
1408\end{array}$ \\
\hline Beooster Eede & 4,595 & 152 & 218 & 870 & 870 & 174 \\
\hline Bewester Eede & 2,112 & 70 & & 240 & 50 & \\
\hline Blankenberge & 15,162 & 517 & & 72 & 215 & 431 \\
\hline De Broeke & 792 & 60 & & & 26 & 26 \\
\hline Dierkinsteenpolder & 175 & 89 & 10 & & & \\
\hline Eeklo (Slepeldamme) & 2,028 & 19 & 26 & & 38 & 77 \\
\hline Eiesluis & 4,378 & 166 & 448 & 715 & 584 & 676 \\
\hline Groede & $634^{\mathrm{b}}$ & 9 & 154 & 175 & 36 & 90 \\
\hline Kamerlings & 7,053 & 67 & 401 & 267 & 134 & \\
\hline $\begin{array}{l}\text { Maldegem } \\
\text { (Slepeldamme) }\end{array}$ & 4,861 & 545 & 122 & 193 & & 184 \\
\hline Noord-over-de-Lieve & 713 & 24 & & & 101 & 48 \\
\hline Oude Yevene & 3,426 & 260 & 790 & 684 & 573 & 559 \\
\hline Reigarsvliet & 6,182 & 146 & & & 146 & 59 \\
\hline Romboutswerve & 427 & 19 & 12 & 16 & 12 & \\
\hline $\begin{array}{l}\text { Schoondijke- } \\
\text { Vrabersdijke }\end{array}$ & $634^{\mathrm{b}}$ & 0 & 120 & 180 & 36 & 24 \\
\hline Serwoutermanswatering & 3,922 & 186 & 133 & 80 & 37 & 149 \\
\hline Sint-Laureins & $2,441^{\mathrm{b}}$ & 81 & & 137 & & \\
\hline Tussen beide Zwinnen & 130 & 6 & 5 & 5 & 33 & 202 \\
\hline Vladslo & $4,840^{\mathrm{b}}$ & 548 & 657 & 160 & 275 & 0 \\
\hline Ysenpolder & 22 & 4 & 1 & & 2 & 2 \\
\hline Zuid-over-de-Lieve & 1,555 & & & & 44 & 81 \\
\hline Total & 66,080 & 2,968 & 3,095 & 3,796 & 3,214 & 2,781 \\
\hline
\end{tabular}

${ }^{a}$ The acreages in this table represent the taxable or fiscal acreage of the water boards, which might differ from the real acreage. They are based on fifteenth- and sixteenth-century accounts and land registers from the water boards. For the districts Groede and Schoondijke-Vrabersdijke only their joint size in 1567 is known, which has been arbitrarily divided by 2 .

$b$ Estimates.

Source: Based on the accounts of St John's hospital in Bruges.

investment in 21 water boards can be reconstructed, based on the scot (or water tax) that landowners had to pay in each of these water boards from 1403 until 1408, as presented in Table 1.

Every year about 3,000 1. groten had to be invested in drainage and flood control in these 21 water boards near Bruges. Of course in difficult years, for example the storm year of 1404-1405, investments were higher. This picture remains partial: there were more than 100 autonomous water 
districts in the fifteenth-century castellany, or district, of Bruges, with a total size of about 100,000 hectares. ${ }^{21}$ In my sample, the larger and more inland water districts are over-represented, whereas data are scarce on the many more exposed small embankments along the Western Scheldt estuary and on the former islands of Wulpen, Kadzand and Koezand at the mouth of the estuary, where flooding problems were particularly high in this period. As a result, the actual capital investment must have been considerably higher. Nevertheless, my sample gives an idea of the capital flow in the organisation of water management: 3,000-4,000 1. groten was about the average budget of Ghent, the largest city in the Low Countries around $1400 .{ }^{22}$ The budget of smaller cities in coastal Flanders such as Damme or Ostend (which had, respectively, about 1,900 and about 750 inhabitants in 1469) ranged between 100 to 3001 . groten $^{23}$, whereas the gross demesne income of the count of Flanders can be estimated at about 14,000 1. groten in the same period. ${ }^{24}$ For the rural economy, a comparison with grain prices or rural wages also stresses the financial importance of water management: in the first decade of the fifteenth century, 3,000 1. groten corresponded to 22,640 hectolitres of wheat ${ }^{25}$ or 160,000 days of unskilled labour. ${ }^{26}$ The area covered by the water boards listed in Table 1 measured about 66,000 hectares, so a labour input of about 2.5 days per hectare is implied. As smallholding farms of $2-5$ hectares were still widespread in this area around 1400, a peasant family would have devoted 5 to 12.5 days a year to water works, or alternatively needed to sell 68 to 170 litres of wheat. With net physical production of wheat oscillating around 1,000 to 1,600 litres per hectare (discounting seed sown) ${ }^{27}$, this seems relatively modest, but of course water taxes complemented other types of taxes such as tithes and land rents levied by landowners and direct and indirect taxes levied by the central government. Furthermore, only part of the acreage of the peasant farm could be devoted to wheat and only part of the latter's product could be sold on the market. As a result, it can be concluded that expenditure for water management did substantially burden the income of a peasant smallholder in the early fifteenth-century coastal plain.

In order to analyse the long-term evolution of capital investment throughout the late medieval period, I reconstructed the water taxes levied by two larger water boards, each of them representative for one part of the Flemish coastal plain. The Blankenbergse Watering (about 17,000 hectares) was situated along the North Sea coast between Bruges, the small town of Oudenburg, and the two ports of Ostend and Blankenberge. It was relatively sheltered from the direct impact of the sea by a natural dune range. Investments in this region were systematically and substantially lower than in my second test area, the Oude Yevene Watering 


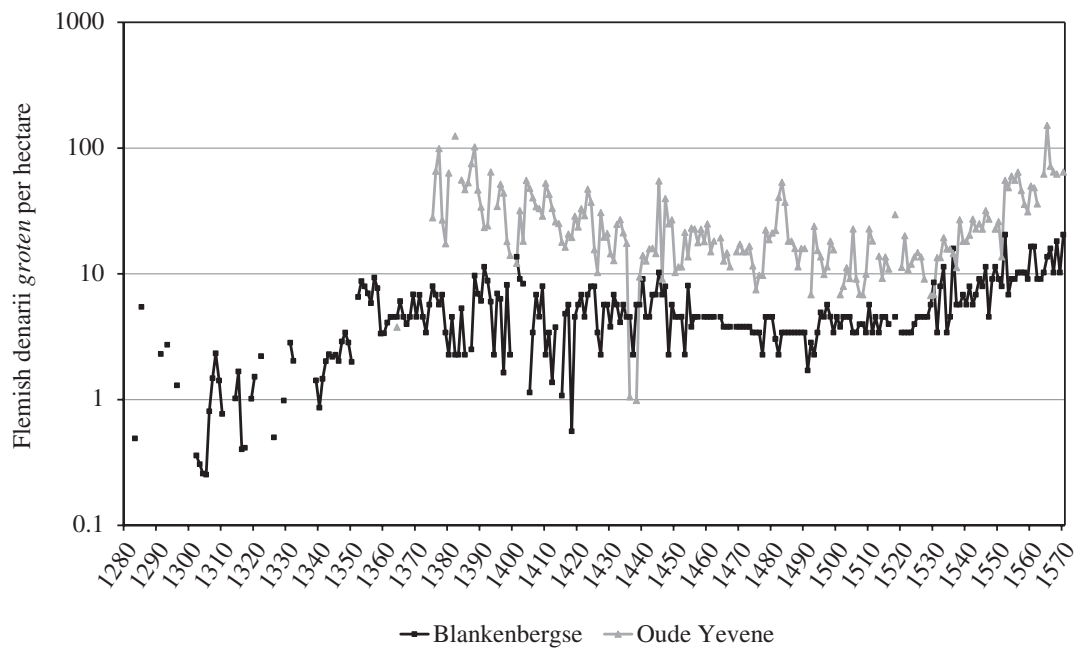

FiguRE 2. Water taxes or geschot in the Blankenbergse Watering and Oude Yevene Watering (Flemish d. groten per hectare), 1280-1570. (Source: see Appendix.)

(about 3,143 hectares), situated in present-day Zeeland-Flanders along the Western Scheldt estuary. Due to the expansion of this estuary in the late medieval period, the area was exposed to significant flooding, and the sea walls had to be rebuilt on different occasions. Notwithstanding this important difference in flood risk between both areas, the long-term evolution of water taxes was almost identical (Figure 2). After an impressive rise during the fourteenth century, nominal taxes peaked in both water boards in the decades before and after 1400. Part of the fourteenthcentury increase is explained by heavy coin debasements during the reign of the Flemish counts Louis de Nevers and Louis de Male, when the silver content of the Flemish denarius (d.) groten shrunk from 3.6 grams in 1331 to 1.2 grams in $1384 .{ }^{28}$ However, as water taxes in the Blankenbergse Watering rose from about $1 \mathrm{~d}$. groten per hectare around 1300, to about $6 \mathrm{~d}$. groten in the second half of that century, the increase of water taxes still exceeded the degree of monetary depreciation.

Thirteenth- and fourteenth-century investments were highly variable, indicative of an investment policy that was very responsive to water problems. Part of the short-term fluctuations in Figure 2 can be related to extreme weather and flooding: storm surges, such as the ones that hit the Flemish coast in 1375-1376 and 1404, are visible as peaks in the level of investments, though sometimes with a delay of several years. The highest levels of investment were not reached in storm years, but in times of large 


\section{TABLE 2}

Unskilled labourers employed by the Blankenbergse Watering (average daily wages in Flemish d. groten; employment in days of unskilled labour), sample years 1285-1408

\begin{tabular}{llrccc}
\hline \hline Financial year & Wages & Employment & Financial year & Wages & Employment \\
\hline $1285-1286$ & 0.6 & 12,908 & $1478-79$ & 6 & 1,808 \\
$1293-1294$ & 0.75 & 2,274 & $1488-89$ & 6 & 1,192 \\
$1304-1305$ & 0.45 & 11,844 & $1498-99$ & 6 & 1,609 \\
$1343-1344$ & 1 & 9,831 & $1520-21$ & 6 & 1,433 \\
$1354-1355$ & 1.5 & 23,788 & $1528-29$ & 6 & 1,557 \\
$1364-1365$ & 3 & 9,742 & $1538-39$ & 6 & 1,675 \\
$1374-1375$ & 4.75 & 3,207 & $1548-49$ & 7 & 2,505 \\
$1383-1384$ & 4 & 763 & $1559-60$ & 8 & 617 \\
$1407-1408$ & 4.75 & 2,777 & $1568-69$ & 12 & 891 \\
Average & & 7,386 & Average & & 1,476 \\
\hline \hline
\end{tabular}

Source: Accounts of the Blankenbergse Watering; see Appendix.

construction programmes, as in 1387-1389, when the Oude Yevene Watering tried to counter the threat of a growing sea encroachment or inlet - the Braakman - by constructing a whole new sea wall along the water board's south eastern frontier. In the Blankenbergse Watering too, the 1350s witnessed higher levels of nominal investment than the 1370 s although the 1350 s are not particularly known for repeated storm flooding.

Investments in drainage and flood control were extremely labour intensive. For the sixteenth-century Netherlands, Bas van Bavel has estimated that dyking and draining activities accounted for 6 per cent of the total labour input in the countryside in Holland. This kind of labour was mostly seasonal and could be a perfect addition to agricultural and protoindustrial activities in a peasant economy, as maintenance works were often concentrated during periods of the year when the demand for labour on the farms was low. ${ }^{29}$ In the thirteenth and early fourteenth centuries the Flemish water boards did offer such seasonal employment to large numbers of locally hired wage-labourers, often including whole families with women and children. Already in the oldest surviving accounts of the Blankenbergse Watering, impressive numbers of operarii (manual workers) supervised by foremen are mentioned. ${ }^{30}$ In $1354-1355$ this water board even employed 23,788 man-days of unskilled labour (Table 2). On a yearly basis this would imply the permanent employment of about 100 people in this single water board. 
This kind of massive labour input was only possible thanks to the availability of abundant and cheap labour, and, until the 1350s, labour was indeed abundant and cheap in the Flemish coastal plain: wages paid by the water boards in coastal Flanders were substantially lower than comparable wages paid in other parts of Flanders. ${ }^{31}$

In the first decades of my enquiry, peak demand for capital was frequently covered by an appeal to short-term loans contracted at the Bruges money market, which was at that time the most sophisticated money market in northern Europe. ${ }^{32}$ Water boards such as the Blankenbergse Watering contracted loans on a short to very short term (a couple of weeks to one year) and paid the high interest rates that were usual for this kind of short-term debt not mortgaged on real estate: 24 to 40.1 per cent of interest a year, the latter being close to the official maximum interest rate of 43.33 per cent. At the end of the financial year 1293-1294 the shortterm debts of the Blankenbergse Watering had increased to 137 1. groten. The interests paid amounted to 22.11 . groten or 11 per cent of the total expenses of the water board in that year. ${ }^{33}$ Paying such high interest rates on short-term loans only made sense in a situation where a significant proportion of landowners lacked money for cash payment of taxes. It was not very profitable for larger landowners with sufficient cash. Not surprisingly, water boards stopped contracting these kinds of short-term loans early in the fourteenth century, and even withdrew completely from the credit market until the middle of the sixteenth century.

\section{DECLINING INVESTMENTS AFTER 1400}

Somewhere around 1400 the long-term tendency of rising nominal investments in the water control system was reversed. In my two test cases, this happened first in the Oude Yevene Watering, where the high level of investment of the 1380s would not be reached again until the 1560 s. Some decades later, a similar drop in investment levels also occurred in my second test case, the Blankenbergse Watering (Figure 2). The pronounced depression of investment levels from about 1425 to 1525 is a general phenomenon seen all over the Flemish coastal plain; it is also visible in the aggregate investments made by large institutional landowners such as St John's hospital in Bruges, which owned more than 1,000 hectares of land in almost 40 different water boards (see Appendix). The lower investment levels cannot be explained by monetary problems ${ }^{34}$ nor by a drop in environmental problems; among many others the years 1446, 1468, 1477, 1509, 1516 and 1530 brought important flood damage along the North Sea coasts. Furthermore, problems caused by the drainage of inland water also tended to increase in this period. In many 
North Sea wetlands, centuries of peat drainage had induced a process of shrinking - compaction - of the peat and a lowering of the soil level, which again resulted in an increase of drainage-related problems. To continue arable farming, artificial drainage through windmill pumping was considered necessary. The first drainage windmill appeared in Holland in the early fifteenth century and their numbers were to multiply in the course of the sixteenth century. In Flanders artificial drainage remained exceptional, but some parts of the coastal plain did become too wet for arable farming and were converted into fishing and bird-hunting grounds. ${ }^{35}$ In the Oude Yevene Watering, low-lying and wet 'pits' multiplied in the landscape, evidence of the local peat-digging activities. ${ }^{36}$ Furthermore, the ecological stability of the dune barrier that protected the Flemish coast was under permanent threat of over-exploitation through pasturing, reed cutting and the breeding of rabbits. Over-exploited dunes became prone to sand-drift and sometimes started to 'wander', covering arable land or even complete settlements. Interestingly, preventive measures against over-exploitation were taken at the end of the fourteenth century and again in the first quarter of the sixteenth century, with a noticeable gap in the fifteenth century. ${ }^{37}$

Lower investments also meant lower labour input. After 1400 the direct engagement of labourers by the Blankenbergse Watering seldom exceeded 2,000 man-days a year, way below the mid-fourteenth-century levels (Table 2). Starting in the second half of the fourteenth century, wages of both unskilled and skilled labourers had begun to rise steeply, both in nominal and in real terms. In the coastal plain this rise was even more pronounced than in inland Flanders: after 1400 higher wages were paid for unskilled labour in the coastal plain than in inland Flanders where the peasant economy was less touched by the late medieval crisis. ${ }^{38}$ As a consequence, water boards in the fifteenth century were increasingly tempted to cut wage labour and to avoid relying too greatly on labourers. The same evolution has been noticed elsewhere: before the Black Death Canterbury Cathedral Priory readily invested in water control projects on its marshland estates in Romney Marsh in southern England. This willingness rapidly faded after 1350 , however, when manpower was becoming scarce and expensive. ${ }^{39}$ To some extent the more frequent appeal to contractors replaced the diminished hiring of wage labourers. As these contractors worked with fixed, negotiated rates for specific tasks, it is difficult to calculate their actual labour. ${ }^{40}$ However, as both wage labourers and contractors were paid from the water taxes, and these taxes remained depressed until the second quarter of the sixteenth century, it is certain that the high level of labour input reached in the thirteenth and fourteenth centuries was never matched again in the subsequent period. 
One could argue that in response to the declining local labour supply in the fifteenth and sixteenth centuries, water boards turned to labour-saving technologies. There undeniably were technical improvements in this period, notably the introduction of the drainage windmill or polder mill; the mechanisation of outlet sluices, now equipped with larger sluice chambers, and double doors in copper fittings; the introduction of brick and stone for sluice construction; the construction of bulwarks and all kinds of groynes and dyke reinforcements made of wood, brushwood and stone. Their introduction was, however, a slow and regionally divergent process, depending less on technological possibilities than on socio-economic and political circumstances. With regard to labour-intensive dyke works, for instance, many water boards in the coastal plain during the fifteenth and sixteenth centuries opted to replace a damaged dyke by building a new dyke behind the old one, rather than buying expensive materials like stone and wood to construct groynes and to upgrade the existing dykes - much to the despair of hydraulic engineers and experts such as Andreas Vierlingh who fiercely promoted the new techniques. ${ }^{41}$ By building new inland dykes time and again, some areas gradually gave way to the sea. In the short term, however, the giving up of a limited area of land often seemed the cheapest solution.

Not only were water taxes low during most of the fifteenth century, yearly fluctuations also tended to diminish. ${ }^{42}$ This is particularly clear in the Blankenbergse Watering, where a tax between 1.5 or $2 \mathrm{~d}$. groten per gemet ( 0.44 hectares) was levied for at least 59 years between 1450 and 1525. In their quest for maximum tax stability, water boards even experimented with leasing out the totality of regular maintenance works for a fixed amount per year. ${ }^{43}$ In 1454 the Eiesluis Watering, west of Bruges, even intended to lease out ordinary maintenance of outlet sluice, ditches, bridges and roads for a period of 20 years. ${ }^{44}$ The contract was presented as an opportunity to enhance the quality of the infrastructure - for instance, by making the gradual replacement of all wooden bridges in the area and the partial replacement of the outlet sluice obligatory - and contractors had to agree on strict procedures of monitoring and sanctioning. Nevertheless, when public works in the Ancien Régime were outsourced, cost reduction was often the most important incentive, followed by the promotion of the private interests of contractors. It is not known whether the 1454 contract ever took effect, and, if so, whether the contract lasted for the intended period of 20 years. What is clear, however, is the fact that in the decade after 1454 the average water tax in the Eiesluis Watering only amounted to $3.1 \mathrm{~d}$. groten per gemet against 4.7 in the previous decade, with the standard deviation falling down from 3.1 to $0.9 .^{45}$ The other side of the coin was the need for an allowance of some kind of risk 
premium, as the contractors risked losing their gains if, for example, the outlet sluice broke down during the course of their contract.

From the mid-sixteenth century onwards, water boards also returned to the credit market, but now in order to engage in the sale of annuities, a widespread instrument in both the public and the private credit markets at that time. In the Blankenbergse Watering, it was the severe storm surge of All Saints Day in 1570 that prompted the board to borrow a substantial amount of money for the first time in two centuries: 1,129 l. groten on a total budget of 2,479 1. groten (46 per cent). ${ }^{46}$ In a period of high inflation and modest interest rates (6.25 per cent), the burden of these loans was relatively low and enabled the sixteenth-century water boards to avoid abrupt increases of water taxes and to stick as long as possible to their policy of low and predictable taxes. ${ }^{47}$ The interest burden nevertheless contributed to the gradual rise of water taxes that has been noticed for the second half of the sixteenth century. The same can be noticed in the seventeenth and eighteenth centuries, when structurally higher levels of investment would usually be accompanied by a much more frequent appeal to the credit market by the water boards. ${ }^{48}$

As environmental challenges remained high, yet investments dropped in the fifteenth century, it might be concluded that the close link that had existed between environmental challenges and water management funding until about 1400 was relaxed in the following decades. In other words: the responsiveness of investments to environmental problems decreased significantly. Other North Sea wetlands witnessed a similar evolution; along the English Thames estuary, for instance, increased flooding problems in the fourteenth century were initially matched by a strong increase in both investments in the water control system and in the issuing of 'commissions de wallis et fossatis' (commissions of sewers) to supervise drainage and flood protection by the English crown. After 1370, however, activities regarding flood management declined, although the environmental problems did not. ${ }^{49}$ How can this be explained? Why did the link between investments and environmental problems dissolve somewhere around 1400 ?

4. THE OPPORTUNITY COST OF INVESTING IN WATER CONTROL

In order to explain the increasing preference for low and predictable investments, I must turn finally to the economic strategies deployed by the major landlords that came to dominate the land market and the water boards. For the period of the Ancien Régime it is often very hard to find reliable data on the share of the agricultural produce or rent that landlords were prepared to reinvest in agriculture. ${ }^{50}$ Bas van Bavel has recently 
assembled the available evidence on rent investment in the late medieval period for different parts of the North Sea area. Adding maintenance and repair works to existing holdings, investments in the transformation of land use, the building of new farms, and the maintenance and improvement of infrastructure, estimates for England, France and the Low Countries indicate a total reinvestment of no more than 12 to 16 per cent. Only in some areas of rapid commercialisation, such as the Dutch River Area, rental investment increased to 16 or 20 per cent of the gross income. ${ }^{51}$ Surprisingly, B. A. Holderness noticed equally low shares in eighteenth- and nineteenth-century East Anglia, even though this was a region of rapid economic development. From 1746 to 1870, landlords' expenditure on various Norfolk and Suffolk estates oscillated between 7 and 15 per cent of their gross rental income..$^{52}$ Holderness's data revealed significant variation over time, with periods of higher investment alternating with periods of lower expenditure. This has been confirmed for inland Flanders by Erik Thoen who has noted a significant decrease in rental investments from 15 to 20 per cent in the early fifteenth century to less than 10 per cent in the last quarter of that century, only reluctantly followed by a modest recovery in the course of the sixteenth century. ${ }^{53}$ Furthermore, recent literature tends to stress the active role of landowners in setting out farming practices and capital investment on their estates. David Stone, for instance, has demonstrated how English landlords and their stewards actively responded to changing economic circumstances by adapting the management strategy of their demesnes. When prices for agricultural products were too low and initiatives for raising productivity were not rewarding, landlords would opt to reduce or postpone investments. ${ }^{54}$

In a region where short-term leaseholding was the dominant form of tenure, the net income of a landlord depended on the evolution of lease prices minus the reinvestments. Before 1350 average lease prices for individual plots of land had been high. Data are still limited for this early period, but lease prices of about $50 \mathrm{~d}$. groten per hectare seem common in the Flemish coastal plain around $1280 .{ }^{55}$ The currency depreciation that started in the late thirteenth century was initially matched by an increase in nominal lease prices, reaching an average level of about $100 \mathrm{~d}$. groten per hectare around 1350. Converted into wheat, this meant a fairly attractive yearly income for the landowner of about 400 to 700 litres per hectare, easily allowing the payment of water taxes that rarely exceeded the equivalent of 50 litres of wheat per hectare (see above). From the second half of the fourteenth century on, however, things were about to change. Not only were nominal lease prices in coastal Flanders no longer adapted to the heavy coin debasements of that period, they also became 
TABLE 3

Average lease prices and water taxes per hectare in the Blankenbergse and Oude Yevene Watering (1445-1574)

\begin{tabular}{|c|c|c|c|c|c|c|}
\hline & \multicolumn{3}{|c|}{ Blankenbergse } & \multicolumn{3}{|c|}{ Oude Yevene } \\
\hline & $\begin{array}{c}\text { Leases }^{a} \\
(d . \text { groten } / h a)\end{array}$ & $\begin{array}{c}\text { Water tax } \\
(d . \text { groten } / h a)\end{array}$ & $\begin{array}{c}\text { Water } \\
\text { tax/lease } \\
(\%)\end{array}$ & $\begin{array}{c}\text { Leases }^{a} \\
(d . \text { groten } / h a)\end{array}$ & $\begin{array}{c}\text { Water tax } \\
(\text { d. } \text { groten } / h a)\end{array}$ & $\begin{array}{c}\text { Water } \\
\text { tax/lease } \\
(\%)\end{array}$ \\
\hline $1445-1454$ & 66.7 & 5.7 & 8.5 & 105.8 & 22.3 & 21.1 \\
\hline $1455-1464$ & 68.9 & 4.0 & 5.7 & 96.6 & 20.2 & 20.9 \\
\hline $1465-1474$ & 69.0 & 3.7 & 5.4 & 92.5 & 14.3 & 15.5 \\
\hline $1475-1484$ & 73.0 & 3.5 & 4.8 & 93.3 & 24.2 & 26.0 \\
\hline $1485-1494$ & 70.3 & 3.1 & 4.4 & 89.4 & 14.1 & 15.8 \\
\hline 1495-1504 & 57.0 & 4.5 & 7.9 & 73.4 & 11.5 & 15.7 \\
\hline $1505-1514$ & 59.0 & 4.0 & 6.7 & 70.1 & 13.3 & 18.9 \\
\hline $1515-1524$ & 59.6 & 3.8 & 6.4 & 69.5 & 15.2 & 21.9 \\
\hline $1525-1534$ & 71.4 & 5.9 & 8.2 & 79.6 & 12.6 & 15.8 \\
\hline $1535-1544$ & 101.0 & 7.4 & 7.3 & 105.2 & 20.0 & 19.0 \\
\hline $1545-1554$ & 133.0 & 9.8 & 7.3 & 106.8 & 34.1 & 32.0 \\
\hline $1555-1564$ & 166.2 & 11.0 & 6.6 & 126.0 & 47.6 & 37.8 \\
\hline $1565-1574$ & 175.6 & 14.8 & 8.4 & 125.6 & 82.7 & 65.9 \\
\hline
\end{tabular}

${ }^{a}$ The lease prices are the author's own calculations based on A. Verstockt, Conjunctuurstudie van een domein in de late Middeleeuwen. Het West Zeeuws-Vlaams domein van de Gentse Sint-Pietersabdij in Oostburg Ambacht aan de hand van pachtprijzen (unpublished MA thesis, Ghent, 1998) and L. Verstappen, Pachtprijzen als conjunctuurmeters (unpublished MA thesis, Ghent, 2001).

Sources: Lease prices are based on the accounts of the Magdalene hospital in Bruges and the Ghent abbey of St Peter. For water taxes, see the Appendix.

structurally depressed for more than a century. When a systematic comparison between lease prices and re-investments in the water control system becomes possible from the 1440s onwards, lease prices in the Blankenbergse Watering did not exceed $70 \mathrm{~d}$. groten per hectare, and would further drop to less than $60 \mathrm{~d}$. groten around 1500. Even though gross rental income was falling lower and lower, re-investments in the water control system never demanded more than 8.5 per cent of this amount, which was only possible thanks to the above-described policy of low and predictable water taxes (Table 3).

In the Blankenbergse Watering, an average re-investment of 5 to 8 per cent in the water control system still left some room for other investments by the landowners. This was perhaps less the case in other parts of coastal Flanders, such as the Oude Yevene Watering, where a permanent investment of more than 15 per cent of the gross rent income was needed to 
ensure drainage and flood protection. To a certain extent, the higher maintenance cost of the water control system in more exposed districts close to the North Sea or the Scheldt estuary was matched by somewhat higher return rates, as the soil in these districts usually consisted of young and fertile clay sediments, yielding higher profits for arable farming. ${ }^{56}$ This comparative advantage would gradually disappear in the course of the sixteenth century; by 1535 lease prices in the Oude Yevene Watering barely equalled the level of 1445, while in the Blankenbergse Watering they had increased by more than 50 per cent. When the 1530 s brought a new decade of severe storm surges in the Western Scheldt region - the most ravaging ones occurring on 5 November 1530 and 2 November 1532 - rental income in the Oude Yevene Watering came under serious pressure. Faced with renewed inundations, and in a context of high inflation, maintaining the low investment levels of the previous decades was no longer an option. However, with the gross rent income of leasedout land only reluctantly increasing, any rise in water taxes consumed landowners' net profits. By the 1570s, the difference between the two areas had become overwhelming: whereas in the Blankenbergse Watering reinvestments in water management still did not exceed 10 per cent, landowners in the Oude Yevene Watering had to invest more than 60 per cent of their gross rent income in the water control system - clearly a much higher rate of capital investment than landowners were normally prepared to make. Making it even worse was the fact that the rising water taxes that swallowed landowners' profits in the sixteenth century in the Oude Yevene Watering hardly improved the quality of the infrastructure. Nominal investments in the third quarter of the sixteenth century equalled investment levels of the late fourteenth century (Figure 2). In the meantime the cost of labour and raw materials had risen significantly, so that water boards could realise fewer projects with the same budget.

In the income strategy of a large landowner, with landed properties scattered all over the coastal plain, such divergences in net income could not remain unnoticed. In terms of return on investment, it became highly questionable to continue investments in the most endangered areas, let alone to raise the taxes necessary for the large-scale application of the new but capital-intensive technologies needed for dyke reinforcement and drainage that began to spread in the fifteenth and sixteenth centuries. Generally speaking, landowners tried to restrict investments in such areas as much as possible, with flight of capital and subsequent flooding problems as a consequence. This is most clearly illustrated by the tragic history of the islands that were once situated near the mouth of the Western Scheldt estuary. Wulpen was the largest of these; in the thirteenth century there were still five parishes on the island, but by the mid-sixteenth 
century it had virtually ceased to exist. ${ }^{57}$ Much better documented is the case of Biervliet, a small coastal town once famous for its salt-refining industry and herring fishery. From the second half of the fourteenth century onwards the city was gradually invaded by the expanding Western Scheldt estuary and turned into a remote island, faced with depopulation, general economic decline and bankruptcy. Two important Benedictine abbeys in Ghent - St Peter and St Bavo - both owned land in Biervliet and its surroundings. Until the beginning of the fifteenth century both abbeys invested considerable amounts of money to safeguard and if necessary recover their possessions. In the small polder of Boterzande in the immediate surroundings of Biervliet, the abbey of St Peter paid an average yearly water tax of 152.6 d. groten per hectare between 1397 and 1421. In those years average lease prices seldom exceeded $100 \mathrm{~d}$. groten per hectare and thus the abbey's land exploitation of the polder was clearly running into deficit. When, in 1421, a new storm surge flooded the polder, the abbey of St Peter and many other landowners were no longer willing to invest in dyke repair. Flemish dyke law stipulated a swift expropriation of landowners unwilling or unable to pay for the water control system, transferring their land to anyone willing to pay the water taxes. This so-called 'right to abandon' (droit d'abandon) allowed landowners to get rid of economically unviable possessions. In 1421 there was only one candidate to take over the abandoned land: the city of Biervliet itself. The other Ghent abbey - St Bavo - held onto its possessions in Biervliet for half a century longer. But after a rat plague and a devastating civil war in the 1480s, St Bavo tried to get rid of its possessions in Biervliet as well, claiming that the gross annual income of its land in Biervliet did not exceed $440 \mathrm{~d}$. groten, while in 1483 alone the abbey had to spend 9600 d. groten on dyke maintenance and repair works. ${ }^{58}$ After an initial period of high investment large landowners like the two Ghent abbeys clearly sought to get rid of their land, preferring to abandon it rather than to continue investing in this unprofitable property, and finally handing over the entire burden of the flood risk to the remaining local inhabitants. ${ }^{59}$

In order to understand the policy of many fifteenth- and sixteenthcentury landlords of limiting investments in the water control system on their coastal estates, one final element has to be taken into account, namely the opportunity cost of such investments as opposed to the alternative strategy of increasing income by acquiring additional land.$^{60}$ From the fourteenth to the sixteenth centuries the land market in the Flemish coastal plain witnessed a massive transfer of landed property from peasant smallholders to larger landlords, including nobles, churches, and village elites, but above all to the burghers from the buoyant Flemish towns ${ }^{61}$ In the absence of a systematic study of the land market in this area, evidence 
TABLE 4

Distribution of landownership in several water boards in the Flemish coastal plain

\begin{tabular}{lccccc}
\hline \hline Water board & Year & $\begin{array}{c}\text { Size } \\
\text { (hectares) }\end{array}$ & $\begin{array}{c}\text { Landowners } \\
(n)\end{array}$ & $\begin{array}{c}\text { Landowners } \\
<5 \text { ha }(n)\end{array}$ & $\begin{array}{c}\text { Landowners } \\
>25 \text { ha }(n)\end{array}$ \\
\hline Oude Yevene (Oostburg) & 1388 & 3,530 & 1,461 & 1,289 & 9 \\
& 1550 & 3,129 & 448 & 303 & 28 \\
Romboutswerve (near Damme) & 1456 & 421 & 151 & 128 & 1 \\
& 1545 & 423 & 78 & 55 & 4 \\
Moerkerke Zuid-over-de-Lieve & 1470 & 2,060 & 323 & 234 & 16 \\
& 1530 & 1,731 & 186 & 120 & 16 \\
Blankenbergse (polder area) & 1513 & 14,746 & 1,190 & 652 & 133 \\
& 1560 & 15,044 & 1,067 & 567 & 150 \\
\hline \hline
\end{tabular}

Sources: Calculations are based on the land registers of the water boards listed. See T. Soens, De spade in de dijk? Waterbeheer en rurale samenleving in de Vlaamse kustvlakte (1280-1580), Historische Economie en Ecologie (Ghent, 2009), 73-112.

of land accumulation by bourgeois and other landlords can be found in the land registers of the water boards, which are available from the late fourteenth century onwards; in every sample taken, large land ownership expanded at the expense of peasant smallholders. By the middle of the sixteenth century, most land in the Flemish coastal plain was owned by absentee landowners; in the district of Moerkerke-Zuid-over-de-Lieve, for instance, 10 kilometres east of Bruges, bourgeois landowners owned 45 per cent of the land, against 31.5 per cent held by religious institutions and 21.5 per cent by local villagers (see Table 4). ${ }^{62}$

Furthermore, there was also a second opportunity for landowners to acquire land at relatively cheap rates: participating in the re-embankment of inundated areas. From the fifteenth century onwards, an active trade in property rights of inundated land and salt marshes came into existence, often with speculative characteristics. Apparently, for some elite groups, investing in inundated areas was more attractive than spending money on existing dykes elsewhere, both for economic and extra-economic reasons. Re-embankment permitted them to create a new landscape perfectly adapted to the needs of a large-scale commercial agriculture. In the reembanked polders, infrastructure, settlement pattern and field system had been planned in a rational and rectilinear way, very different from the scattered and chaotic organisation of the medieval wetlands. ${ }^{63}$ The risks were often high, but when the embankment succeeded, the economic return was usually good: when, in 1502, the abbey of St Peter in Ghent 
participated in the embankment of the Jeronimus polder in Western Zeeland-Flanders, they paid $545 \mathrm{~d}$. groten per hectare for the acquisition of the land and $723 \mathrm{~d}$. groten per hectare for the embankment itself. ${ }^{64}$ In that period leasing out the land yielded between 60 and $70 \mathrm{~d}$. groten per hectare, which would imply that the initial investment was repaid in about 20 years, equivalent to an annual return of 5 per cent. Furthermore, the new embankments also generated social prestige for investors with lots of capital but a lack of ancestors. There are many fifteenth- and sixteenth-century examples of investors, often belonging to a new, office-holding elite, who grasped the opportunity of embankments to create estates and seigneuries, to build churches and villages, to obtain privileges and titles, as necessary complements to their steep ascent in society. ${ }^{65}$

\section{CONCLUSION}

In the coastal wetlands of the North Sea area permanent investment in drainage and flood control was, and still is, needed to enable human occupation and (arable) farming. Balancing out the different elements that determine the level of capital investment in coastal wetlands, it seems possible to offer a structural explanation for long-running developments without having to rely too heavily on physical externalities. Indeed, the frequency of extreme climate events such as storm surges might have increased in the fourteenth and sixteenth centuries, but their impact on capital investment was in most cases short-lived and highly dependent on economic circumstances. In this respect, I can agree with Jan de Vries who, in 1981, stated that 'short-term climate crises stand in relation to economic history as bank robberies to the history of banking ${ }^{6}{ }^{66}$ Instead, I have considered investments in the water control system as a specific form of re-investment of agricultural income, which in the end depended on the income strategies of landowners and farmers. Peasant smallholders, who dominated the rural economy of the Flemish coastal plain until the fourteenth century, clearly pursued different income and investment strategies from the absentee landowners and commercial tenant farmers who steadily replaced them during the course of the later Middle Ages. In the Flemish coastal plain, the concentration of property, the rise of absentee landownership and the spread of leaseholding apparently hampered the rise of capital investment in drainage and flood control rather than accelerating it. Whereas the rise of capital investment in the fourteenth century had surpassed inflation, real investments became depressed throughout most of the fifteenth and sixteenth centuries, due to a policy of low and predictable water taxes. 
Trying to understand why the re-investment of agricultural income stagnated or even dropped when the coastal economy was becoming increasingly commercialised, I have looked at changes in the organisation of water management funding. In the greater Bruges area a companylike structure was adopted at a very early stage: water boards which ensured the maintenance and repair of the water control system acted increasingly as vehicles for capital investment, with the goal of protecting the financial interests of their major shareholders. The liability of these shareholders was limited to the share of land they owned within the territory of a water board. The financial consequences of this rule were completely different for peasant smallholders than for large absentee landowners: for the former group, the limited liability was mere fiction, as their family capital was entirely concentrated in one area, and a severe dyke breach or flooding could be fatal for them. With family survival at stake, it was logical for peasant landowners to avoid this kind of problem as much as possible. In this view, the risk aversion that made peasants cling to open field practices also induced them to invest considerable amounts of labour and money in the water control system.

For larger and absentee landowners, (short-term) financial profitability rather than safety was increasingly the determining factor in the level of capital investment. In the fifteenth and sixteenth centuries this profitability was best served by low and stable levels of investment. With gross lease income per hectare decreasing throughout most of the fifteenth and sixteenth centuries, the opportunity cost of investing more than 10 per cent of rental income was too high, not least because more rewarding alternatives were available. In this period, large landowners clearly preferred purchasing more land rather than improving their old land. They could pursue this strategy, because land was abundant in the coastal plain, due both to the collapse of the peasant economy and to frequent flooding. The environmental consequences were important: for the major shareholders of the water boards, with possessions scattered all over the coastal plain, it was rational to accept a higher environmental risk in order to safeguard the short-term profitability of their landed property. In the case of flooding, the limited liability protected them against financial claims they did not want to honour, whereas in the longer term it also created opportunities for renewed expansion of landed property through reembankment. In fragile areas, decades of low capital investment in the end led to diminishing returns, flights of capital and flooding. As such, economic change, not climate change, was a major driving force behind some of the most famous 'natural' disasters in the late medieval North Sea area. 


\section{A P P ENDIX}

Investments in drainage and flood control in the Flemish coastal plain, 1280-1580

\begin{tabular}{|c|c|c|c|c|}
\hline Year & $\begin{array}{l}\text { Blankenbergse } \\
\text { Watering: water } \\
\text { taxes (Flemish } \\
d . \text { groten } \\
\text { per hectare) }\end{array}$ & $\begin{array}{c}\text { Oude Yevene } \\
\text { Watering: } \\
\text { water taxes } \\
\text { (Flemish } d \text {. groten } \\
\text { per hectare) }\end{array}$ & $\begin{array}{l}\text { St John's hospital in } \\
\text { Bruges: total investment } \\
\text { in the water control } \\
\text { system (Flemish d. } \\
\text { groten per } 240 \text { hectares) }\end{array}$ & $\begin{array}{c}\text { Wages of unskilled } \\
\text { labourers employed } \\
\text { in water works } \\
\text { (Flemish } d \text {. groten } \\
\text { per day) }\end{array}$ \\
\hline \multicolumn{5}{|l|}{1277} \\
\hline \multicolumn{5}{|l|}{1278} \\
\hline \multicolumn{5}{|l|}{1279} \\
\hline 1280 & & & 98.7 & \\
\hline 1281 & & & 120.6 & \\
\hline \multicolumn{5}{|l|}{1282} \\
\hline 1283 & 0.5 & & 165.5 & \\
\hline \multicolumn{5}{|l|}{1284} \\
\hline 1285 & $5.4^{*}$ & & & 0.6 \\
\hline 1286 & 0 & & 117.7 & \\
\hline \multicolumn{5}{|l|}{1287} \\
\hline 1288 & 0 & & 161.0 & \\
\hline 1289 & 0 & & 146.8 & \\
\hline 1290 & & & 72.7 & \\
\hline 1291 & 2.3 & & 296.6 & \\
\hline 1292 & 0 & & & 0.8 \\
\hline 1293 & $2.7^{*}$ & & 301.7 & 0.8 \\
\hline \multicolumn{5}{|l|}{1294} \\
\hline \multicolumn{5}{|l|}{1295} \\
\hline 1296 & $1.3^{*}$ & $*$ & & 0.8 \\
\hline 1297 & $0^{*}$ & $*$ & & 0.7 \\
\hline \multicolumn{5}{|l|}{1298} \\
\hline 1299 & & & 122.8 & \\
\hline \multicolumn{5}{|l|}{1300} \\
\hline \multicolumn{5}{|l|}{1301} \\
\hline 1302 & $0.4^{*}$ & & & 0.6 \\
\hline 1303 & $0.3^{*}$ & & & 0.5 \\
\hline 1304 & $0.3^{*}$ & & & 0.5 \\
\hline 1305 & $0.3^{*}$ & & & 0.6 \\
\hline 1306 & $0.8^{*}$ & & 390.5 & 0.6 \\
\hline 1307 & $1.5^{*}$ & & & 0.8 \\
\hline 1308 & 2.3 & & 271.8 & \\
\hline 1309 & 1.4 & & 362.9 & \\
\hline 1310 & 0.8 & & 197.7 & \\
\hline \multicolumn{5}{|l|}{1311} \\
\hline \multicolumn{5}{|l|}{1312} \\
\hline \multicolumn{5}{|l|}{1313} \\
\hline 1314 & 1 & & 220.8 & \\
\hline 1315 & 1.7 & & 295.9 & \\
\hline
\end{tabular}


Appendix (Cont.)

\begin{tabular}{|c|c|c|c|c|}
\hline Year & $\begin{array}{l}\text { Blankenbergse } \\
\text { Watering: water } \\
\text { taxes (Flemish } \\
\text { d. groten } \\
\text { per hectare) }\end{array}$ & $\begin{array}{c}\text { Oude Yevene } \\
\text { Watering: } \\
\text { water taxes } \\
\text { (Flemish } \text {. } \text { groten } \\
\text { per hectare) }\end{array}$ & $\begin{array}{l}\text { St John's hospital in } \\
\text { Bruges: total investment } \\
\text { in the water control } \\
\text { system (Flemish d. } \\
\text { groten per } 240 \text { hectares) }\end{array}$ & $\begin{array}{c}\text { Wages of unskilled } \\
\text { labourers employed } \\
\text { in water works } \\
\text { (Flemish } d \text {. groten } \\
\text { per day) }\end{array}$ \\
\hline 1316 & 0.4 & & 118.7 & \\
\hline 1317 & 0.4 & & 152.2 & \\
\hline \multicolumn{5}{|l|}{1318} \\
\hline 1319 & 1 & & 246.2 & \\
\hline 1320 & 1.5 & & 302.0 & \\
\hline \multicolumn{5}{|l|}{1321} \\
\hline 1322 & 2.2 & & 562.2 & \\
\hline \multicolumn{5}{|l|}{1323} \\
\hline 1324 & & & 149.0 & \\
\hline \multicolumn{5}{|l|}{1325} \\
\hline 1326 & 0.5 & & 154.8 & \\
\hline 1327 & & & 169.1 & \\
\hline \multicolumn{5}{|l|}{1328} \\
\hline 1329 & 1 & & 340.4 & \\
\hline \multicolumn{5}{|l|}{1330} \\
\hline 1331 & 2.8 & & 473.6 & \\
\hline 1332 & 2 & & 403.5 & \\
\hline \multicolumn{5}{|l|}{1333} \\
\hline \multicolumn{5}{|l|}{1334} \\
\hline \multicolumn{5}{|l|}{1335} \\
\hline \multicolumn{5}{|l|}{1336} \\
\hline \multicolumn{5}{|l|}{1337} \\
\hline \multicolumn{5}{|l|}{1338} \\
\hline 1339 & $1.4^{*}$ & & 198.6 & 0.8 \\
\hline 1340 & 0.9 & & 121.8 & \\
\hline 1341 & 1.4 & & 228.9 & \\
\hline 1342 & 2 & & 409.9 & 1.0 \\
\hline 1343 & $2.3^{*}$ & & 371.8 & 1.0 \\
\hline 1344 & 2.2 & & 366.3 & \\
\hline 1345 & $2.3^{*}$ & & 385.0 & 1.0 \\
\hline 1346 & 2 & & 381.8 & \\
\hline 1347 & 2.9 & & 431.4 & \\
\hline 1348 & $3.4^{*}$ & & 597.0 & 1.0 \\
\hline 1349 & $2.8^{*}$ & & & 1.0 \\
\hline 1350 & $2.0^{*}$ & & 599.4 & 1.0 \\
\hline \multicolumn{5}{|l|}{1351} \\
\hline 1352 & 6.5 & & $1,244.6$ & \\
\hline 1353 & 8.7 & & $1,474.3$ & \\
\hline 1354 & $7.9^{*}$ & & $1,157.6$ & 1.5 \\
\hline 1355 & 6.9 & & $1,059.1$ & \\
\hline 1356 & 5.8 & & 926.9 & \\
\hline
\end{tabular}


Appendix ( Cont.)

\begin{tabular}{|c|c|c|c|c|}
\hline Year & $\begin{array}{l}\text { Blankenbergse } \\
\text { Watering: water } \\
\text { taxes (Flemish } \\
\text { d. groten } \\
\text { per hectare) }\end{array}$ & $\begin{array}{c}\text { Oude Yevene } \\
\text { Watering: } \\
\text { water taxes } \\
\text { (Flemish } d \text {. groten } \\
\text { per hectare) }\end{array}$ & $\begin{array}{l}\text { St John's hospital in } \\
\text { Bruges: total investment } \\
\text { in the water control } \\
\text { system (Flemish d. } \\
\text { groten per } 240 \text { hectares) }\end{array}$ & $\begin{array}{c}\text { Wages of unskilled } \\
\text { labourers employed } \\
\text { in water works } \\
\text { (Flemish } d \text {. groten } \\
\text { per day) }\end{array}$ \\
\hline 1357 & 9.2 & & $1,537.3$ & 2.0 \\
\hline 1358 & 7.6 & & $1,604.1$ & \\
\hline 1359 & 3.3 & & 973.0 & \\
\hline 1360 & 3.3 & & 985.3 & \\
\hline 1361 & 4.1 & & $1,102.5$ & \\
\hline 1362 & 4.5 & & $1,336.9$ & \\
\hline 1363 & $4.5^{*}$ & & $1,189.5$ & 2.5 \\
\hline 1364 & $4.5^{*}$ & 3.8 & $1,373.1$ & 3.0 \\
\hline 1365 & $6 *$ & & $1,088.0$ & \\
\hline 1366 & $4.5^{*}$ & & $1,128.0$ & 3.0 \\
\hline 1367 & $3.9^{*}$ & & 855.9 & 2.3 \\
\hline 1368 & $4.5^{*}$ & & $1,062.9$ & 3.5 \\
\hline 1369 & 6.8 & & $1,336.5$ & \\
\hline 1370 & $4.5^{*}$ & & $1,343.0$ & 3.5 \\
\hline 1371 & $6.7^{*}$ & & $1,677.1$ & 3.5 \\
\hline 1372 & $4.5^{*}$ & & $1,094.6$ & 4.3 \\
\hline 1373 & $3.4^{*}$ & & 885.7 & 3.8 \\
\hline 1374 & $5.6^{*}$ & & $1,733.6$ & 4.8 \\
\hline 1375 & $7.9^{*}$ & 27.9 & $2,571.0$ & 3.0 \\
\hline 1376 & $6.8^{*}$ & 65.6 & & 3.1 \\
\hline 1377 & $5.6^{*}$ & 98.8 & & 3.3 \\
\hline 1378 & $6.8^{*}$ & 26.7 & & 3.8 \\
\hline 1379 & $3.4^{*}$ & 17.3 & & 4.5 \\
\hline 1380 & $2.3^{*}$ & 63.3 & & 4.0 \\
\hline 1381 & $4.5^{*}$ & & $1,295.0$ & 4.0 \\
\hline 1382 & $2.3^{*}$ & 124.3 & $1,134.4$ & 4.0 \\
\hline 1383 & $2.3^{*}$ & & $2,091.1$ & 4.0 \\
\hline 1384 & 5.3 & 55.6 & 803.0 & \\
\hline 1385 & $2.3^{*}$ & 46.6 & 316.0 & \\
\hline 1386 & 0 & 53.0 & 668.4 & \\
\hline 1387 & 2.5 & 75.2 & $1,600.0$ & \\
\hline 1388 & 9.6 & 102.0 & $3,321.3$ & \\
\hline 1389 & 6.9 & 46.3 & $2,875.2$ & \\
\hline 1390 & 6 & 33.9 & $2,119.1$ & \\
\hline 1391 & $11.3^{*}$ & 23.4 & $2,595.6$ & \\
\hline 1392 & 8.7 & 24.1 & $1,732.8$ & \\
\hline 1393 & 5.9 & 64.4 & $1,651.0$ & \\
\hline 1394 & 2.3 & & $1,629.3$ & \\
\hline 1395 & 6.9 & 34.3 & $1,624.4$ & \\
\hline 1396 & 6.3 & 51.5 & $1,153.0$ & \\
\hline 1397 & 1.6 & 44.0 & $1,143.6$ & \\
\hline
\end{tabular}


Appendix (Cont.)

\begin{tabular}{|c|c|c|c|c|}
\hline Year & $\begin{array}{l}\text { Blankenbergse } \\
\text { Watering: water } \\
\text { taxes (Flemish } \\
d . \text { groten } \\
\text { per hectare) }\end{array}$ & $\begin{array}{c}\text { Oude Yevene } \\
\text { Watering: } \\
\text { water taxes } \\
\text { (Flemish } \text {. } \text { groten } \\
\text { per hectare) }\end{array}$ & $\begin{array}{l}\text { St John's hospital in } \\
\text { Bruges: total investment } \\
\text { in the water control } \\
\text { system (Flemish d. } \\
\text { groten per } 240 \text { hectares) }\end{array}$ & $\begin{array}{c}\text { Wages of unskilled } \\
\text { labourers employed } \\
\text { in water works } \\
\text { (Flemish d. groten } \\
\text { per day) }\end{array}$ \\
\hline 1398 & 8.1 & 18.1 & $1,335.1$ & \\
\hline 1399 & 2.3 & 14.0 & $1,814.3$ & 5.0 \\
\hline 1400 & & & & 4.0 \\
\hline 1401 & 13.5 & 12.1 & $2,356.7$ & \\
\hline 1402 & 9 & 31.8 & $2,251.6$ & \\
\hline 1403 & 8.3 & 18.2 & $1,922.6$ & \\
\hline 1404 & 0 & 55.3 & $1,833.6$ & \\
\hline 1405 & 1.1 & 47.9 & $2,462.1$ & \\
\hline 1406 & 3.4 & 40.1 & $2,577.1$ & \\
\hline 1407 & $6.8^{*}$ & $34.1^{*}$ & $3,346.2$ & 4.8 \\
\hline 1408 & $4.5^{*}$ & $33.0^{*}$ & $1,921.6$ & 5.0 \\
\hline 1409 & $7.9^{*}$ & 28.7 & $1,673.7$ & 5.0 \\
\hline 1410 & 2.3 & 52.6 & $1,752.0$ & \\
\hline 1411 & 3.4 & 42.7 & $1,820.2$ & \\
\hline 1412 & 1.4 & 33.2 & $1,360.2$ & \\
\hline 1413 & 3.7 & 25.9 & $1,754.1$ & \\
\hline 1414 & 0 & 25.1 & 823.5 & \\
\hline 1415 & 1.1 & 17.8 & 849.6 & \\
\hline 1416 & 4.8 & 16.3 & $1,322.6$ & \\
\hline 1417 & 5.6 & 20.7 & $1,683.6$ & 5.0 \\
\hline 1418 & 0.6 & 19.5 & $1,527.4$ & \\
\hline 1419 & 4.5 & 28.7 & $1,122.0$ & \\
\hline 1420 & 5.6 & 23.5 & $1,300.6$ & \\
\hline 1421 & 6.8 & 33.0 & $1,870.3$ & \\
\hline 1422 & 4.5 & 29.0 & $1,513.8$ & \\
\hline 1423 & 6.8 & 47.2 & $1,746.6$ & 5.0 \\
\hline 1424 & 7.9 & 37.1 & $1,988.8$ & \\
\hline 1425 & 7.9 & 15.5 & $1,877.6$ & \\
\hline 1426 & 3.4 & 10.2 & $1,122.8$ & \\
\hline 1427 & 2.3 & 30.7 & $1,427.5$ & \\
\hline 1428 & 5.6 & 19.6 & $1,501.7$ & \\
\hline 1429 & 5.6 & 20.9 & $1,592.4$ & \\
\hline 1430 & 3.8 & 14.5 & $1,192.9$ & \\
\hline 1431 & 6.8 & 12.8 & $1,529.9$ & \\
\hline 1432 & 5.6 & 24.7 & $1,390.4$ & 6.0 \\
\hline 1433 & 4.1 & 26.9 & $1,452.7$ & \\
\hline 1434 & 5.6 & 21.2 & $1,201.1$ & \\
\hline 1435 & 4.5 & 17.5 & $1,304.4$ & \\
\hline 1436 & 4.5 & 1.1 & 701.2 & \\
\hline 1437 & 2.3 & 0.0 & 440.6 & \\
\hline 1438 & 5.6 & 1.0 & $1,178.9$ & 6.0 \\
\hline
\end{tabular}


Appendix ( Cont.)

\begin{tabular}{|c|c|c|c|c|}
\hline Year & $\begin{array}{l}\text { Blankenbergse } \\
\text { Watering: water } \\
\text { taxes (Flemish } \\
d \text {. groten } \\
\text { per hectare) }\end{array}$ & $\begin{array}{c}\text { Oude Yevene } \\
\text { Watering: } \\
\text { water taxes } \\
\text { (Flemish } \text {. } \text { groten } \\
\text { per hectare) }\end{array}$ & $\begin{array}{l}\text { St John's hospital in } \\
\text { Bruges: total investment } \\
\text { in the water control } \\
\text { system (Flemish } d \text {. } \\
\text { groten per } 240 \text { hectares) }\end{array}$ & $\begin{array}{c}\text { Wages of unskilled } \\
\text { labourers employed } \\
\text { in water works } \\
\text { (Flemish } d \text {. groten } \\
\text { per day) }\end{array}$ \\
\hline 1439 & 5.6 & 9.5 & $1,312.5$ & \\
\hline 1440 & 9 & 14.0 & $2,050.1$ & \\
\hline 1441 & 4.5 & 12.6 & $1,574.1$ & \\
\hline 1442 & 4.5 & 15.8 & $2,234.0$ & 4.0 \\
\hline 1443 & 6.8 & 16.0 & $1,698.0$ & 6.0 \\
\hline 1444 & 6.8 & 14.5 & $1,999.2$ & \\
\hline 1445 & 10.1 & 54.8 & $2,613.0$ & \\
\hline 1446 & 6.8 & 9.1 & $1,688.8$ & \\
\hline 1447 & 7.9 & 39.6 & $3,104.0$ & \\
\hline 1448 & 2.3 & 25.0 & $1,273.1$ & \\
\hline 1449 & 5.6 & 26.8 & $1,612.7$ & \\
\hline 1450 & 4.5 & 10.2 & $1,430.7$ & 5.0 \\
\hline 1451 & 4.5 & 11.4 & $1,655.0$ & 6.0 \\
\hline 1452 & 4.5 & 11.4 & 960.0 & 6.0 \\
\hline 1453 & 2.3 & 21.3 & 755.0 & \\
\hline 1454 & 8 & 13.6 & $2,050.7$ & \\
\hline 1455 & 3.8 & 23.1 & $1,288.8$ & \\
\hline 1456 & 4.5 & 22.7 & $1,349.8$ & \\
\hline 1457 & 4.5 & 17.7 & $1,096.7$ & \\
\hline 1458 & 0 & 22.6 & $1,182.0$ & \\
\hline 1459 & 4.5 & 18.0 & $1,506.2$ & \\
\hline 1460 & 4.5 & 24.9 & $1,540.2$ & \\
\hline 1461 & 4.5 & 15.0 & $1,118.7$ & \\
\hline 1462 & 4.5 & 18.2 & $1,125.0$ & \\
\hline \multicolumn{5}{|l|}{1463} \\
\hline 1464 & 4.5 & 19.3 & $1,208.8$ & \\
\hline 1465 & 3.8 & 12.6 & $1,125.6$ & \\
\hline 1466 & 3.8 & 14.7 & $1,531.4$ & \\
\hline 1467 & 3.8 & 11.4 & $1,337.7$ & 6.0 \\
\hline 1468 & & & & 6.0 \\
\hline 1469 & 3.8 & 15.0 & $1,577.2$ & \\
\hline 1470 & 3.8 & 17.2 & $1,556.4$ & \\
\hline 1471 & 3.8 & 15.0 & 964.6 & \\
\hline 1472 & 3.8 & 15.0 & $1,271.4$ & \\
\hline 1473 & 3.8 & 16.6 & $1,580.4$ & \\
\hline 1474 & 3.4 & 11.5 & $1,068.0$ & \\
\hline 1475 & 3.4 & 7.4 & 889.6 & \\
\hline 1476 & 3.4 & 9.7 & 741.7 & \\
\hline 1477 & $2.3^{*}$ & 9.7 & 828.3 & 6.0 \\
\hline 1478 & $4.5^{*}$ & 22.3 & $1,194.6$ & 6.0 \\
\hline 1479 & $4.5^{*}$ & 18.7 & $1,225.9$ & 6.0 \\
\hline
\end{tabular}


Appendix (Cont.)

\begin{tabular}{|c|c|c|c|c|}
\hline Year & $\begin{array}{l}\text { Blankenbergse } \\
\text { Watering: water } \\
\text { taxes (Flemish } \\
d . \text { groten } \\
\text { per hectare) }\end{array}$ & $\begin{array}{c}\text { Oude Yevene } \\
\text { Watering: } \\
\text { water taxes } \\
\text { (Flemish } \text {. } \text { groten } \\
\text { per hectare) }\end{array}$ & $\begin{array}{l}\text { St John's hospital in } \\
\text { Bruges: total investment } \\
\text { in the water control } \\
\text { system (Flemish d. } \\
\text { groten per } 240 \text { hectares) }\end{array}$ & $\begin{array}{c}\text { Wages of unskilled } \\
\text { labourers employed } \\
\text { in water works } \\
\text { (Flemish d. groten } \\
\text { per day) }\end{array}$ \\
\hline 1480 & $4.5^{*}$ & 21.1 & $1,150.7$ & 5.5 \\
\hline 1481 & $3^{*}$ & 22.1 & $1,285.6$ & 6.0 \\
\hline 1482 & $2.3^{*}$ & 40.5 & $1,254.3$ & 6.0 \\
\hline 1483 & 3.4 & 53.4 & $1,777.0$ & \\
\hline 1484 & $3.4^{*}$ & 37.1 & $1,942.3$ & 6.0 \\
\hline 1485 & 3.4 & 18.2 & 999.1 & \\
\hline 1486 & $3.4^{*}$ & 18.2 & $1,060.4$ & 6.0 \\
\hline 1487 & 3.4 & 15.9 & 861.8 & \\
\hline 1488 & $3.4^{*}$ & 11.4 & 799.6 & 6.0 \\
\hline 1489 & $3.4^{*}$ & 15.9 & 738.2 & 6.0 \\
\hline 1490 & 3.4 & 15.9 & 543.8 & \\
\hline 1491 & 1.7 & 0.0 & 174.2 & \\
\hline 1492 & 2.8 & 6.8 & 463.7 & \\
\hline 1493 & $2.3^{*}$ & 23.9 & 838.7 & 6.0 \\
\hline 1494 & $3.4^{*}$ & 15.4 & $1,357.3$ & 6.0 \\
\hline 1495 & 4.9 & 13.6 & $1,171.9$ & \\
\hline 1496 & $4.5^{*}$ & 9.9 & $1,184.2$ & 6.0 \\
\hline 1497 & $5.6^{*}$ & 11.4 & $1,238.7$ & 6.0 \\
\hline 1498 & $4.5^{*}$ & 18.2 & $1,299.7$ & 6.0 \\
\hline 1499 & $3.4^{*}$ & 15.5 & $1,287.5$ & 6.0 \\
\hline 1500 & $4.5^{*}$ & & $1,031.5$ & 6.0 \\
\hline 1501 & $3.8^{*}$ & 6.8 & $1,087.8$ & 6.0 \\
\hline 1502 & $4.5^{*}$ & 8.0 & $1,140.2$ & 6.0 \\
\hline 1503 & $4.5^{*}$ & 11.2 & $1,308.1$ & 6.0 \\
\hline 1504 & $4.5^{*}$ & 9.2 & $1,230.7$ & 6.0 \\
\hline 1505 & $3.4^{*}$ & 22.7 & $1,166.2$ & 6.0 \\
\hline 1506 & $3.4^{*}$ & 9.1 & 939.9 & 6.0 \\
\hline 1507 & $3.9^{*}$ & 6.9 & 911.7 & 6.0 \\
\hline 1508 & $3.9^{*}$ & 6.8 & 938.3 & 7.0 \\
\hline 1509 & $3.4^{*}$ & 9.9 & 977.4 & 6.0 \\
\hline 1510 & $5.6^{*}$ & 22.7 & $1,502.9$ & 6.0 \\
\hline 1511 & $3.4^{*}$ & 18.2 & $1,019.5$ & 6.0 \\
\hline 1512 & $4.5^{*}$ & & & 6.0 \\
\hline 1513 & 3.4 & 13.8 & $1,130.1$ & 6.0 \\
\hline 1514 & 4.5 & 9.2 & $1,057.8$ & \\
\hline 1515 & 4.5 & 13.6 & $1,736.6$ & 6.0 \\
\hline 1516 & 3.9 & 10.9 & $1,414.4$ & 6.0 \\
\hline 1517 & & & & 6.0 \\
\hline 1518 & 4.5 & 29.5 & $1,843.3$ & 6.0 \\
\hline 1519 & & & & \\
\hline 1520 & $3.4^{*}$ & 11.2 & $1,094.0$ & 6.0 \\
\hline
\end{tabular}


Appendix ( Cont.)

\begin{tabular}{|c|c|c|c|c|}
\hline Year & $\begin{array}{l}\text { Blankenbergse } \\
\text { Watering: water } \\
\text { taxes (Flemish } \\
d . \text { groten } \\
\text { per hectare) }\end{array}$ & $\begin{array}{c}\text { Oude Yevene } \\
\text { Watering: } \\
\text { water taxes } \\
\text { (Flemish } d \text {. groten } \\
\text { per hectare) }\end{array}$ & $\begin{array}{l}\text { St John's hospital in } \\
\text { Bruges: total investment } \\
\text { in the water control } \\
\text { system (Flemish } d \text {. } \\
\text { groten per } 240 \text { hectares) }\end{array}$ & $\begin{array}{c}\text { Wages of unskilled } \\
\text { labourers employed } \\
\text { in water works } \\
\text { (Flemish } d \text {. groten } \\
\text { per day) }\end{array}$ \\
\hline 1521 & $3.4^{*}$ & 20.1 & $1,260.9$ & 6.0 \\
\hline 1522 & 3.4 & 10.8 & $1,054.6$ & \\
\hline 1523 & $3.4^{*}$ & 11.9 & $1,009.7$ & 6.0 \\
\hline 1524 & 3.9 & 13.6 & $1,120.2$ & \\
\hline 1525 & $4.5^{*}$ & 14.8 & $1,271.4$ & 6.0 \\
\hline 1526 & $4.5^{*}$ & 13.6 & $1,105.3$ & 6.0 \\
\hline 1527 & $4.5^{*}$ & 9.1 & $1,166.0$ & 6.0 \\
\hline 1528 & $4.5^{*}$ & & & 6.0 \\
\hline 1529 & $5.6^{*}$ & 6.7 & $1,422.8$ & 5.0 \\
\hline 1530 & $8.5^{*}$ & 6.8 & $3,299.6$ & 6.0 \\
\hline 1531 & 3.4 & 13.5 & $3,045.8$ & \\
\hline 1532 & $7.9^{*}$ & 13.5 & $3,149.7$ & 6.0 \\
\hline 1533 & $11.3^{*}$ & 19.4 & $2,898.3$ & 6.0 \\
\hline 1534 & $3.4^{*}$ & 15.7 & $1,397.1$ & 7.0 \\
\hline 1535 & $4.5^{*}$ & 15.7 & $1,727.5$ & 7.0 \\
\hline 1536 & $15.8^{*}$ & 14.5 & $2,443.0$ & 6.0 \\
\hline 1537 & $5.6^{*}$ & 11.2 & $1,426.5$ & 6.0 \\
\hline 1538 & $5.6^{*}$ & 27.0 & $1,616.0$ & 6.0 \\
\hline 1539 & 6.8 & 18.1 & $1,932.8$ & \\
\hline 1540 & 5.6 & 18.1 & $1,375.0$ & \\
\hline 1541 & 7.9 & 20.3 & $1,610.6$ & \\
\hline 1542 & 5.6 & 27.2 & $1,496.4$ & \\
\hline 1543 & 6.8 & 22.7 & $1,541.4$ & \\
\hline 1544 & 9 & 25.0 & $1,806.5$ & \\
\hline 1545 & $7.9^{*}$ & 22.7 & $1,714.5$ & 6.0 \\
\hline 1546 & $11.3^{*}$ & 31.8 & $1,971.9$ & 7.0 \\
\hline 1547 & 4.5 & 27.2 & $1,599.2$ & \\
\hline 1548 & $9^{*}$ & & & 7.0 \\
\hline 1549 & $11.3^{*}$ & 22.7 & $2,902.9$ & 7.0 \\
\hline 1550 & $9 *$ & 26.0 & $2,670.4$ & 7.0 \\
\hline 1551 & $7.9^{*}$ & 13.6 & $1,764.5$ & 8.0 \\
\hline 1552 & $20.3^{*}$ & 55.2 & $3,992.3$ & 8.0 \\
\hline 1553 & $6.8^{*}$ & 48.3 & $1,757.9$ & 8.0 \\
\hline 1554 & 9 & 59.8 & $2,683.9$ & \\
\hline 1555 & 9 & 55.4 & $2,860.3$ & \\
\hline 1556 & 10.1 & 64.3 & $2,635.9$ & \\
\hline 1557 & 10.1 & 46.0 & $2,297.1$ & \\
\hline 1558 & 10.1 & 35.6 & $1,473.6$ & \\
\hline 1559 & $9^{*}$ & 31.1 & $1,338.4$ & 8.0 \\
\hline 1560 & 16.4 & 49.9 & $3,094.9$ & \\
\hline 1561 & 16.4 & 48.3 & $4,124.3$ & \\
\hline
\end{tabular}


Appendix (Cont.)

\begin{tabular}{lcccc}
\hline \hline & $\begin{array}{c}\text { Blankenbergse } \\
\text { Watering: water } \\
\text { taxes (Flemish } \\
\text {. groten } \\
\text { per hectare) }\end{array}$ & $\begin{array}{c}\text { Oude Yevene } \\
\text { Watering: } \\
\text { water taxes } \\
\text { Flemish } \text {. groten } \\
\text { per hectare) }\end{array}$ & $\begin{array}{c}\text { St John's hospital in } \\
\text { Bruges: total investment } \\
\text { in the water control } \\
\text { system (Flemish } \text {. } \\
\text { groten per 240 hectares) }\end{array}$ & $\begin{array}{c}\text { Wages of unskilled } \\
\text { labourers employed } \\
\text { in water works } \\
\text { Flemish } \text {. groten } \\
\text { per day) }\end{array}$ \\
\hline 1562 & $9^{*}$ & 35.9 & $2,378.0$ & 8.0 \\
1563 & $9^{*}$ & & $1,555.2$ & \\
1564 & $10.2^{*}$ & 62.0 & $2,240.0$ & \\
1565 & $13.5^{*}$ & 151.1 & $4,032.5$ & 10.0 \\
1566 & $15.8^{*}$ & 71.7 & $3,120.8$ & 12.0 \\
1567 & $10.1^{*}$ & 64.4 & $2,303.1$ & 11.0 \\
1568 & $18^{*}$ & 62.1 & $3,819.0$ & \\
1569 & $10.1^{*}$ & & $3,693.7$ & \\
1570 & $20.3^{*}$ & 64.4 & & \\
\hline \hline
\end{tabular}

Note on monetary conversions: from the 1290s onwards the monetary policy of the French king Philip IV, followed by the Flemish counts, resulted in a quick devaluation of the denier parisis against the stronger denier groten (gros). Contrary to later periods, the prevailing money of account followed this devaluation. From 1305 onwards confusion grew, as a heavier version of the denier parisis was emitted. The light denier parisis - hence called denier paiement-continued to be used, both as a coin and as money of account. Only around 1317-1319 was the exchange rate of the different types of money of account denier paiement, denier parisis and denier groten finally fixed at 40 to 12 to 1 . See H. Van Werveke, 'Munt en politiek. De Frans-Vlaamse verhoudingen voor en na 1300', Bijdragen voor de geschiedenis der Nederlanden, 8 (1953-1954), 1-2, 11-18. For the period 1285-1303 I followed the conversions in a contemporary document by a monk of the Ghent abbey of Saint-Peter, Machlin van Sint-Baafs, also used by Van Werveke. For the subsequent years conversions in the city accounts of Bruges were used. By using the monetary conversions mentioned in the city accounts of Bruges, it was possible to convert all price and wage data into Flemish denarii groten.

Sources: Columns A, B and C: based on the accounts of St John's hospital in Bruges: Bruges, Archives of the Public Welfare Centre (hereafter BAPW), St John's hospital, accounts G2-G316; Bruges, City Archives (hereafter BCA), series 429, 194-199 and roll 1317; column $\mathrm{D}$ and numbers with * in columns $\mathrm{A}$ and $\mathrm{B}$ based on the accounts of the water boards: BAPW, St John's hospital, water boards, A, boxes 3-4; boxes 10-14; Bruges, Episcopal Archives, A277 and C453; Bruges, State Archives, Watering Blankenberge, 333-339; Watering Eiesluis 141 and 399; Watering Moerkerke-Zuid-over-de-Lieve, 281-386; Franc de Bruges, register 14992-96 and 15167; Ghent, State Archives, St Peter's Abbey, I, Account 1512; BCA, series 523 (346); Brussels, National Archives, Chambre des Comptes, roll 2080.

\section{ACKNOWLEDGEMENTS}

The initial research on which this article is based was conducted during my $\mathrm{PhD}$ research on water management in the medieval Flemish coastal plain. This research was supervised by Erik Thoen at Ghent University (Belgium) from 2000 to 2006. I explicitly wish to thank him for his never-ending support and inspiring ideas, as well as Peter Stabel and Bruno Blondé for their comments on earlier drafts of this article. For language correction, the author is indebted to Imke De Gier. 


\section{ENDNOTES}

1 M. Bailey, 'Per impetum maris: natural disaster and economic decline in eastern England, 1275-1350', in B. M. S. Campbell ed., Before the Black Death (Manchester, 1991), 184-208; A. Gross and A. Butcher, 'Adaptation and investment in the age of the great storms: agricultural policy on the manors of the principal lords of the Romney Marshes and the Marshland fringe, c. 1250-1320', in J. Eddison ed., Romney Marsh. The debatable ground, Oxford University Committee for Archaeology Monograph, no. 41 (Oxford, 1995), 107-17.

2 A. de Kraker, 'Flood events in the southwestern Netherlands and coastal Belgium, 1400-1953', Hydrological Sciences 51, 5 (2006), 913-29; C. Rohr, 'Measuring the frequency and intensity of floods of the Traun River (Upper Austria) 1441-1574', Hydrological Sciences 51, 5 (2006), 834-47.

3 For example, M. Jakubowski-Tiessen, Sturmflut 1717. Die Bewältigung einer Naturkatastrophe in der frühen Neuzeit (Munich, 1992); F. Mauelshagen, 'Flood disasters and political culture at the German North Sea coast: a long term historical perspective', Historical Social Research 32 (2007), 133-44.

4 For example, the Dutch 'Delta' project after the disastrous 1953 flood or more recently, large-scale initiatives taken in the aftermath of 2005 Hurricane Katrina in New Orleans or the 2006 Tsunami in South-East Asia.

5 P. Coombes and K. Barber, 'Environmental determinism in Holocene research: causality or coincidence', Area 37, 3 (2005), 303-11; G. Endfield, 'Reconsidering climate and causality: case studies from colonial Mexico', in S. Sörlin and P. Warde eds., Nature's end. History and the environment (Basingstoke, 2009), 304-6.

6 T. Steinberg, Acts of God. The unnatural history of natural disaster in America (Oxford, 2006); various contributions in G. Massard-Guilbaud, D. Schott and H. Platt eds., Cities and catastrophes: coping with emergency in European history (Frankfurt am Main, 2002); C. Pfister and C. Mauch eds., Natural disasters, cultural responses: case studies towards a global environmental history (Lexington, 2009).

7 de Kraker, 'Flood events', 917-18; 925-6; A. J. Long, J. B. Innes, J. R. Kirby, J. M. Lloyd, M. M. Rutherford, I. Shennan and M. J. Tooley, 'Holocene sea-level change and coastal evolution in the Humber estuary, eastern England: an assessment of rapid coastal change', The Holocene 8, 2 (1998), 229-47; K. E. Behre, 'Coastal development, sea-level change and settlement history during the later Holocene in the Clay District of Lower Saxony (Niedersachsen), northern Germany', Quarternary International 112 (2004), 37-53, here 49; J. C. Knox, 'Large increases in flood magnitude in response to modest changes in climate', Nature 361, 6411 (1993), 430-32.

8 B. A. Holderness, 'Landlord's capital formation in East Anglia 1750-1870', Economic History Review 25 (1972), 434-47; R. Hilton, 'Rent and capital formation in feudal society', in Second International Conference of Economic History: Aix-en-Provence (Paris, 1965), vol. 2, 38-68; B. Campbell, English seigniorial agriculture 1250-1450 (Cambridge, 2000), 14.

9 R. Brenner, 'The agrarian roots of European capitalism', Past and Present 97 (1982), 103; R. Brenner, 'The Low Countries in the transition to capitalism', in P. Hoppenbrouwers and J. L. van Zanden eds., Peasants into farmers? The transformation of rural economy and society in the Low Countries (Middle Ages-19th century) in light of the Brenner debate, CORN Publication Series 4 (Turnhout, 2001), 187-8.

10 J. de Vries, The Dutch rural economy in the Golden Age, 1500-1700 (New Haven, 1974), 196; J. de Vries, 'The transition to capitalism in a land without feudalism', in Hoppenbrouwers and van Zanden, Peasants into farmers?, 78. 
11 R. C. Allen, Enclosure and the yeoman (Oxford, 1992), 191-210.

12 D. McCloskey, 'The prudent peasant: new findings on open fields', Journal of Economic History 51, 2 (1992), 343-55.

13 T. Soens, 'Explaining deficiencies of water management in the late medieval Flemish coastal plain, 13th-16th centuries', Jaarboek voor Ecologische Geschiedenis, 35-61; M. K. E. Gottschalk, Storm surges and river floods in the Netherlands (Assen, 1971-1977), 3 vols.

14 T. Soens and E. Thoen, 'The origins of leasehold in the former county of Flanders', in B. J. P. Van Bavel and P. R. Schofield eds., The development of leasehold in Northwestern Europe, c. 1200-1600, CORN Publication Series 10 (Turnhout, 2008), 31-56.

15 E. Thoen, "“Social agrosystems" as an economic concept to explain regional differences. An essay taking the former county of Flanders as an example (Middle Ages-19th Century)', in B. J. P. van Bavel and P. Hoppenbrouwers eds., Landholding and land transfer in the North Sea area (late Middle Ages-19th century), CORN Publication Series 5 (Turnhout, 2004), 47-66; P. van Cruyningen, Behoudend maar buigzaam. Boeren in West-Zeeuws-Vlaanderen 1650-1850, AAG Bijdragen 40 (Wageningen, 2000).

16 T. Soens, 'Threatened by the sea, condemned by man? Flood risk and environmental inequalities along the North Sea coast (1200-1800 AD)', in G. Massard-Guilbaud and R. Rodger eds., Environmental and social inequalities in the city. Historical perspectives (Cambridge, 2011), 91-111.

17 T. Soens, De spade in de dijk? Waterbeheer en rurale samenleving in de Vlaamse kustvlakte (1280-1580), Historische Economie en Ecologie (Ghent, 2009), 17-57.

18 T. De Moor, 'The silent revolution: a new perspective on the emergence of commons, guilds and other forms of collective action in Western Europe', The International Review of Social History 53 (2008) 16, 1-14.

19 S. Ciriacono, Building on water. Venice, Holland and the construction of the European landscape in early modern times (New York, 2006), 196-250.

20 H. C. Darby, The changing fenland (Cambridge, 1983), 36-56. For a recent reappreciation: M. A. Knittl, 'The design for the initial drainage of the Great Level of the Fens: an historical whodunit in three parts', Agricultural History Review 55, 1 (2007), 23-50.

21 Soens, Spade in de dijk, Appendix. Today, the Flemish coastal plain stretching from Calais in northern France to the Western Scheldt estuary in the north covers about 250,000 hectares of land: my sample thus represents about $65 \%$ of the coastal wetlands within the castellany of Bruges and about $25 \%$ of coastal Flanders. The latter data are based on the actual size of the coastal water districts in the Belgian provinces of WestVlaanderen (99,783 hectares of coastal lands); Oost-Vlaanderen (54,238 hectares); in Zeeland-Flanders (73,150 hectares) and in Northern France (Départements du Nord et du Pas de Calais), estimated at about 30,000 hectares. Source www.vvpw.be (Flemish association of Polders and Wateringues) and http://www.wszv.nl/ (Water District Zeeuws-Vlaanderen).

22 M. Boone, Geld en macht. De Gentse stadsfinanciën en de Bourgondische staatsvorming (1384-1453) (Ghent, 1990), table 6.

23 P. Stabel, Dwarfs among giants. The Flemish urban network in the late Middle Ages (Leuven-Apeldoorn, 1997), 37-8; budgets estimated by T. Soens based on the respective city accounts.

24 T. Soens, 'Evolution et gestion du domaine comtal en Flandre sous Louis de Male et Philippe le Hardi (1346-1404)', Revue-du Nord-Histoire 83, 1 (2001), 25-63. 
25 The average wheat price of 54.7 denarii groten per hoet of 172 litres in 1400-1409 is based on A. Verhulst, 'Prijzen van granen, boter en kaas te Brugge volgens de "slag" van het Sint-Donatiaanskapittel (1348-1801)', in C. Verlinden and E. Scholliers eds., Dokumenten voor de geschiedenis van prijzen en lonen in Vlaanderen en Brabant. Deel II (Bruges, 1965), 34.

26 See Appendix: from 1400 to 1409, an unskilled labourer engaged in maintenance works on the water control system was paid 4 to $5 \mathrm{~d}$. groten a day.

27 J. Mertens, De laat-middeleeuwse landbouweconomie in enkele gemeenten van het Brugse Vrije (Bruges, 1970), 77-9.

28 H. Van Werveke, 'Currency manipulation in the Middle Ages. The case of Louis de Male, count of Flanders', Transactions of the Royal Historical Society (Fourth Series) 31 (1949), 115-27; J. Munro, 'Mint policies, ratios, and outputs in England and the Low Countries, 1335-420: some reflections on new data', The Numismatic Chronicle 141 (1981), 110-11.

29 B. van Bavel, 'Rural wage labour in the sixteenth century Low Countries: an assessment of the importance and nature of wage labour in the countryside of Holland, Guelders and Flanders', Continuity and Change 21, 1 (2006), 42-3 and 62; P. Van Dam, 'Digging for a dike. Holland's labour market ca. 1510', in Hoppenbrouwers and van Zanden, Peasants into farmers?, 222-4.

30 Account of the Blankenbergse Watering 1293-1294, edited by M. Gysseling, Corpus van Middelnederlandse teksten. Reeks I ambtelijke bescheiden (Den Haag, 1977), nr. 1329: 'Operarii de feria sexta post medium aprilem usque translationem Beati Thome DC XXVI man dachwerc pro die VII s. d.: summa 191.11 s. 3 d. Item operarii de translatione Beati Thome usque festum Beati Mathei CCCCLIX man dachwerc pro die IX d. summa 171.4 s. 3 d. ... Johanni Fachelare de bedrivene dikers \& operarios CXVII dies pro die XII d., summa 51.17 s'.

31 E. Thoen, Landbouwekonomie en bevolking in Vlaanderen gedurende de late Middeleeuwen en het begin van de Moderne Tijden. Test-regio: de kasselrijen van Oudenaarde en Aalst (Gent, 1988), 1318-24.

32 J. Murray, Bruges, cradle of capitalism. 1280-1390 (Cambridge, 2005), 177.

33 Gysseling, Account of the Blankenbergse Watering 1293-1294.

34 The silver content of the Flemish d. groten stabilised during the long reign of Phillip the Good of Burgundy (1419-1467). Afterwards the d. groten depreciated from about 0.7 to about 0.5 grams of silver in the first decades of the sixteenth century; see also J. Munro, 'Wage stickiness, monetary changes, and real incomes in late-medieval England and the Low Countries, 1300-1500: did money matter?', Research in Economic History 21 (2003), 185-297.

35 B. Augustyn, 'De landschapsgeschiedenis van de Lage Moer van Meetkerke (13de-20ste eeuw)', in E. Huys and M. Vandermaesen eds., Polders en wateringen. Studiedag georganiseerd te Damme op 19 mei 2000 (Brussels, 2001), 55-64.

36 N. Vanslembrouck, E. Thoen and A. Lehouck, 'Past landscapes and present-day techniques. Reconstructing submerged medieval landscapes in the western part of Sealand Flanders', Landscape History 27 (2005), 5-18.

37 B. Augustyn, 'Evolution of the dune ecosystem in Flanders during the Middle Ages: anthropogenic factors versus sea level change theory', available on http://www.armara.be/augustyn/dune-ecosystem.htm [last accessed on 6 June 2011].

38 Thoen, Landbouwekonomie, 1318-1324. A further article on this subject is being prepared by E. Thoen and T. Soens.

39 Gross and Butcher, 'Adaptation and investment', 116. 
40 S. Wade Martins and T. Williamson, 'Labour and improvement: agricultural change in East Anglia, circa 1750-1870', Labour History Review 62, 3 (1997), 277-9.

41 P. van Dam, 'Ecological challenges, technological innovations. The modernization of sluice building in Holland, 1300-1600', Technology and Culture 43, 3 (2002), 499-520; K. Davids, 'Technological change and the economic expansion of the Dutch Republic, 1580-1680', in K. Davids and L. Noordegraaf eds., The Dutch economy in the Golden Age (Amsterdam, 1993), 79-104.

42 The yearly coefficient of variation of water taxes in the Blankenbergse Watering, converted into silver evolves from $83.8 \%$ between 1280 and 1350 to $58.0 \%$ between 1351 and $1425 ; 50.3 \%$ from 1426 to 1530 and $40.4 \%$ from 1531 to 1580 .

43 Bruges, State Archives [hereafter BSA], Blankenbergse Watering, 334: account of the contractor Jan Barbesaen for the year 1476-1477. The contractor - belonging to a wealthy family from Bruges - received 601 groten a year to be spent on maintenance work, mainly of ditches and roads. Already in 1433 the same water board had negotiated a similar agreement with a contractor for the duration of three years: Bruges, Archives of the Public Welfare Centre [hereafter BAPW], Blankenbergse Watering, box 8 (old number 1A).

44 BAPW, Wateringen, box 11 (old number 2B).

45 BAPW, St John's Hospital, Accounts of the hospital 1444-1463.

46 BSA, Blankenbergse Watering, 339, account of 1570-1577.

47 Ordinary revenues in the period 1549-1570 amounted to 944 1. groten a year on average, while the total burden of interest on the loans contracted in 1570 did not exceed 711 .

48 For Flanders, see T. Faes, De zeewering tussen Blankenberge en Oostende in de moderne tijden (unpublished MA thesis, Ghent, 1966); for Holland, see P. Van Dam and M. Van Tielhof, Waterstaat in Stedenland. Het Hoogheemraadschap van Rijnland voor 1857 (Utrecht, 2006), 238.

49 J. A. Galloway and J. S. Potts, "Marine flooding in the Thames estuary and tidal river c.1250-1450: impact and response', Area 39 (2007), 370-9; J. A. Galloway, 'Storm flooding, coastal defence and land use around the Thames estuary and tidal river c.1250-1450', Journal of Medieval History 35, 2 (2009), 171-88.

50 Hilton, 'Rent and capital formation', 35.

51 B. J. P. Van Bavel, 'Land, lease and agriculture: the transition of the rural economy in the Dutch river area from the fourteenth to the sixteenth century', Past and Present 172 (2001), 30. On the manors of Canterbury Cathedral Priory in Romney Marsh, an average capital expenditure of 32 per cent on gross cash income was reached in the last quarter of the thirteenth century. However, only part of the Priory's income was in cash, which seriously distorts the calculation: Gross and Butcher, 'Adaptation and investment', 112.

52 Holderness, 'Landlord's capital formation', 439.

53 Thoen, Landbouwekonomie, 595-604.

54 D. Stone, Decision-making in medieval agriculture (Oxford, 2005), 121-55.

55 Average based on more than 150 individual leases all over coastal Flanders, assembled by Soens, Spade in de dijk, 136-7.

56 Van Cruyningen, Behoudend maar buigzaam, 181-7.

57 M. K. E. Gottschalk, Historische geografie van Westelijk Zeeuws-Vlaanderen (Assen, 1955-1958), 2 vols.

58 Gottschalk, Historische geografie, II, 19-25; Soens, Spade in de dijk, 102-3.

59 T. Soens, 'Threatened by the sea, condemned by man? Flood risk and environmental inequalities along the North Sea coast (1200-1800 AD)', in G. Massard-Guilbaud and 
R. Rodger eds., Environmental and social inequalities in the city. Historical perspectives (Cambridge, 2011), 102-5.

60 G. Clark, 'The cost of capital and medieval agricultural technique', Explorations in Economic History 25 (1988), 269. See, however, the critics of E.L. Jones, 'Enclosure, land improvement and the price of capital. A comment', Explorations in Economic History 27 (1990), 350-5.

61 Thoen and Soens, The origins of leasehold; D. Nicholas, Town and countryside: social, economic and political tensions in fourteenth-century Flanders (Bruges, 1971), 268-80; E. Thoen, "A medieval "commercial survival economy" in evolution. The Flemish countryside and the transition debate', in Hoppenbrouwers and Van Zanden, Peasants into farmers?, 130-35.

62 Soens, Spade in de dijk, 97-8.

63 Vanslembrouck, Thoen and Lehouck, 'Past landscapes'; P. J. van Cruyningen, 'Profits and risks in drainage projects in Staats-Vlaanderen, c. 1590-1665', Jaarboek voor Ecologische Geschiedenis (2005/2006), 123-42; W. Reh, C. M. Steenbergen and D. Aten, Sea of land. The polder as an experimental atlas of Dutch landscape architecture (Amsterdam, 2006).

64 Ghent, State Archives, St Peter's Abbey, Cartularium 6, f 126, quitclaim dated 6 March 1502.

65 W. De Clercq, J. Dumolyn and J. Haemers, 'Vivre noblement: material culture and elite identity in late medieval Flanders', Journal of Interdisciplinary History 38, 1 (2007), $1-31$.

66 J. de Vries, 'Measuring the impact of climate on history: the search for appropriate methodologies', in R. I. Rotberg and Th. K. Rabb eds., Climate and history. Studies in interdisciplinary history (Princeton, 1981), 23. 